\title{
Pengembangan problem based learning dengan assessment for learning berbantuan smartphone dalam pembelajaran matematika
}

\section{Muhammad Ridlo Yuwono, Muhammad Wahid Syaifuddin ${ }^{1}$}

\begin{abstract}
Abstrak: Penelitian ini bertujuan untuk menghasilkan model Problem Based Learning (PBL) menggunakan penilaian Assessment for Learning (AfL) berbantuan smartphone, disingkat PBL-AfL-S yang valid, praktis dan efektif untuk mendukung implementasi kurikulum 2013 di SMA. Tahap-tahap pengembangan model PBL-AfL-S terdiri daripenelitian pendahuluan, pengembangan/prototyping, dan evaluasi. Kualitas model PBL-AfL-S mengacu pada kriteria kualitas menurut Nieveen (1999) yaitu valid, praktis, dan efektif. Model PBL-AfL-S diujicobakan di SMA Negeri 3 Klaten dalam dua tahap uji coba. Uji coba tahap I dilaksanakan di kelas XI-IPA 6 dan uji coba tahap II dilaksanakan di kelas XI-IPA 7. Instrumen penelitian terdiri dari: 1) Instrumen penilaian kevalidan komponen model dan perangkat pendukung pembelajaran, 2) Instrumen kepraktisan aktivitas guru dan siswa, dan 3) Instrumen keefektifan yang meliputi angket penilaian diri, lembar penilaian proyek, tes prestasi belajar, dan lembar respon siswa. Hasil penelitian menunjukkan bahwa model PBL-AfL-S dan perangkat pembelajarannya telah memenuhi kriteria valid, praktis dan efektif.
\end{abstract}

Kata kunci: Pengembangan; Model Pembelajaran; Masalah; Asesmen; Smartphone

\begin{abstract}
This study aims to develop a Problem Based Learning (PBL) model using Assessment for Learning (AFL) with smartphone-assisted, abbreviated as PBL-AfL-S which fulfills the criteria of valid, practical and effective to support the implementation of the 2013 curriculum in High School. The stages of developing the PBL-AfL-S model consist of preliminary research, development or prototyping, and evaluation. The quality criteria of PBL-AfL-S refer to Nieveen (1999), i.e. valid, practical, and effective. The PBL-AfL-S model was piloted in SMA Negeri 3 Klaten in two phases. Tryout 1 was conducted in class XI-IPA6 and tryout 2 was in class XI-IPA 7. The research instruments consist of: 1) The validity instrument of the model and its learning support tools, 2) the practicality of the teacher's and students' activity, and 3) The effectiveness instruments including self-assessment questionnaires, project appraisal sheets, achievement tests, and student response
\end{abstract}

\footnotetext{
${ }^{1}$ Universitas Widya Dharma, Klaten, Indonesia,ridloyuwono90@gmail.com
} 
sheets. The results show that the PBL-AfL-S model and learning tools have met the valid, practical and effective criteria.

Keywords: Development; Model; Problem based Learning, Assessment; Smartphone

\section{A. Pendahuluan}

Salah satu alternatif pendekatan pembelajaran yang digunakan pada kurikulum 2013 adalah pendekatan saintifik. Menurut Sani (2014), pendekatan saintifik berkaitan erat dengan metode saintifik. Metode saintifik (ilmiah) pada umumnya melibatkan kegiatan pengamatan atau observasi yang dibutuhkan untuk perumusan hipotesis atau mengumpulkan data. Metode ilmiah pada umumnya dilandasi dengan pemaparan data yang diperoleh melalui pengamatan atau percobaan. Pembelajaran dengan integrasi kegiatan ilmiah pada umunya merupakan kegiatan inkuiri. Menurut Sani (2014), inkuiri (inquiry) adalah proses berpikir untuk memahami sesuatu dengan proses pengajuan pertanyaan. Inkuiri dapat dijadikan sebagai pendekatan, strategi, atau metode pembelajaran.

Kegiatan belajar secara inkuiri dapat dilakukan melalui pembelajaran berbasis inkuiri, pembelajaran menemukan (discovery), studi kasus (case study), Problem-based Learning (PBL), Project-based Learning (PjBL), dan sebagainya. Menurut Barrows (1988), pembelajaran berbasis masalah (PBL) didasarkan atas teori konstruktivisme, dimana siswa dilatih mengembangkan pemikiran kritis, pemecahan masalah, dan keterampilan kolaboratif saat mereka mengidentifikasi masalah, merumuskan hipotesis, melakukan pencarian data, melakukan percobaan, merumuskan solusi dan menentukan solusi terbaik untuk memecahkan masalah. Pembelajaran berbasis masalah (PBL) dapat membuat siswa belajar memecahkan masalah dunia nyata secara terstruktur dalam rangka mengonstruksi pengetahuan siswa (Risnawati, 2013) dan mendukung kemampuan berpikir kreatif (Azmi, Irzani, \& Khusnial, 2014).

Penggunaan PBL untuk materi matematika di SMA hendaklah ditelaah kesesuaiannya terlebih dahulu. Hal tersebut dikarenakan beberapa materi yang terdapat pada mata pelajaran matematika di SMA 
lebih menekankan siswa untuk berpikir lebih abstrak dibandingkan dengan siswa SD maupun SMP. Salah satu materi yang bisa disesuaikan dengan PBL adalah konsep turunan fungsi aljabar. Pada materi turunan fungsi aljabar siswa dapat diberikan permasalahan nyata sebagai pengantar pembelajaran untuk mengonstruksi pengetahuannya melalui interaksi dengan lingkungannya. Hasil penelitian Bashith dan Amin (2017) menunjukkan bahwa model pembelajaran PBL mempengaruhi kemampuan berpikir kritis dan hasil belajar siswa di SMAN 6 Malang. Kemampuan berpikir kritis dan hasil belajar siswa pada kelompok eksperimen lebih tinggi daripada kelompok kontrol.

Laporan hasil Ujian Nasional mata pelajaran matematika SMA program IPA Tahun Pelajaran 2014/2015 dari Badan Penelitian dan Pengembangan Kementerian Pendidikan dan Kebudayaan (2014) menyatakan bahwa daya serap siswa dalam menyelesaikan soal aplikasi turunan fungsi untuk tingkat nasional sebesar $40,77 \%$, tingkat Provinsi Jawa tengah sebesar 39,47\%, tingkat Kabupaten Klaten sebesar 34,86, dan untuk SMA Negeri 3 Klaten sebesar 21,91\%. Berdasarkan laporan tersebut dapat dikatakan bahwa daya serap siswa SMA Negeri 3 Klaten dalam menyelesaikan soal aplikasi turunan fungsi lebih rendah jika dibandingkan dengan daya serap tingkat kabupaten, provinsi, maupun nasional.

Daya serap siswa dalam menyeselaikan soal aplikasi turunan fungsi tersebut dapat disebabkan oleh beberapa faktor. Salah satunya adalah penilaian formatif pada penerapan kurikulum 2013 mata pelajaran matematika di sekolah yang kurang optimal. Berdasarkan hasil observasi di kelas XI-IPA 6 dan wawancara dengan guru SMA Negeri 3 Klaten diperoleh informasi bahwa dalam memberikan penilaian guru lebih sering menerapkan penilaian sumatif daripada penilaian formatif. Penilaian yang harus diterapkan di sekolah tidak hanya penilaian sumatif, tetapi juga penilaian formatif. Menurut Sani (2014), penilaian sumatif dilakukan untuk menentukan kemampuan atau kompetensi siswa pada akhir proses pembelajaran. Penilaian formatif dilakukan untuk menilai kemajuan siswa pada waktu tertentu ketika masih belajar dalam upaya memperbaiki pembelajaran.Tujuan penilaian formatif yaitu: 1) memberikan umpan balik siswa dalam meningkatkan belajarnya, 2) sebagai umpan balik bagi guru tentang pelaksanaan pembelajaran, 3) menjamin akuntabilitas proses pembelajaran, 4) meningkatkan motivasi belajar siswa, dan 5) 
mendiagnosis kekuatan dan kekurangan siswa dalam belajar. Dengan adanya umpan balik dari guru atas kesalahan atau kekurangan dalam mengerjakan soal, diharapkan siswa dapat mengetahui letak kesalahan atau kekurangannya serta merasa memperoleh perhatian dari guru dalam proses belajar. Dengan demikian, siswa dapat termotivasi untuk meningkatkan belajarnya supaya memperoleh daya serap yang baik pada materi yang dipelajarinya.

Selama ini guru belum melaksanakan penilaian formatif secara optimal. Guru lebih sering melaksanakan penilaian sumatif. Oleh karena itu, diperlukan suatu model penilaian yang lebih menekankan penilaian formatif dalam implementasi kurikulum 2013 pada mata pelajaran matematika. Penilaian yang dimaksud adalah Assessment for Learning (AfL). Assessment Reform Group (ARG) menyatakan bahwa Assessment for Learning (AfL) merupakan penilaian yang prioritas utama dalam desain dan praktik adalah untuk mengembangkan pembelajaran siswa (Flórez \& Sammons, 2013). Penerapan AfL juga menjadi solusi dalam meningkatkan hasil pembelajaran matematika (Yuwono, 2016; Negara, 2015). Jadi, AfL berbeda dari penilaian yang dirancang terutama untuk melayani keperluan akuntabilitas, atau peringkat, atau sertifikasi kompetensi. Sebuah kegiatan penilaian dapat membantu belajar jika menyediakan informasi untuk digunakan sebagai umpan balik oleh guru, dan oleh siswa dalam menilai diri mereka sendiri dan satu sama lain, untuk mengubah mengajar dan kegiatan dimana semua siswa terlibat belajar.

Hasil penelitian Isabwe, Reichert, Carlsen, dan Lian (2014) menunjukkan bahwa siswa merasa semangat terlibat dalam menilai kinerja matematika siswa lain, yaitu menilai jawaban tugas matematika sesama siswa melalui penilaian AfL. Dengan terlibat dalam proses penilaian, siswa dapat memperoleh keuntungan belajar matematika. Siswa memperoleh dan memberikan umpan balik yang baik dari atau ke sesama siswa dengan menggunakan produk teknologi yang mendukung proses pembelajaran matematika.

Selain memberikan penilaian AfL di kelas, guru juga harus memberikan penilaian AfL di luar kelas (di rumah) untuk memantau belajar siswa di rumah. Hal ini dikarenakan pada kurikulum 2013 menuntut pembelajaran yang tidak hanya di dalam kelas, tetapi juga di luar kelas.Umpan balik saat di luar kelas dapat diberikan guru kepada 
siswa melalui media komunikasi smartphone dengan memanfaatkan aplikasi WhatsApp. Hasil penelitian Naidoo dan Kopung (2016) menunjukkan bahwa penggunaan pesan instan WhatsApp dapat membantu siswa dalam belajar matematika. Penggunaan pesan instan WhatsApp sebagai alat untuk membina lingkungan konstruktivis sosial untuk pembelajaran matematika. Lingkungan ini mendukung siswa dalam meningkatkan kinerjanya dalam matematika.

Model PBL yang memuat kegiatan inkuiri perlu didukung dengan penilaian AfL. Hai ini dikarenakan selain melakukan kegiatan mengontruksi pengetahuan untuk memecahkan masalah, siswa juga perlu diberi umpan balik atas pekerjaan soal dari masalah lain pada materi yang sama supaya siswa meningkatkan belajarnya. Untuk mendukung pelaksanaan AfL pada pelaksanaan model PBL perlu memanfaatkan smartphone dengan menggunakan aplikasi WhatsApp. Dengan memanfaatkan smartphone guru dapat berkomunikasi dengan siswa tanpa harus tatap muka secara langsung dalam rangka memberikan umpan balik terhadap tugas siswa yang dikerjakan di luar kelas (di rumah). Oleh karena itu, perlu untuk mengembangkan model PBL dengan menggunakan model penilaian AfL dengan memanfaatkan smartphone untuk mendukung implementasi kurikulum 2013 di SMA.

\section{B. Metode Penelitian}

Dalam mengembangkan model pembelajaran PBL dengan AfL berbantuan smartphone (disingkat PBL-AfL-S) pada penelitian ini menggunakan desain penelitian pengembangan model Plomp. Menurut Plomp (2013), tahapan pada penelitian pengembangan dalam pendidikan, yaitu:

1. Preliminary research: Pada tahap ini dilakukan analisis kebutuhan berupa observasi ke kelas dan wawancara dengan guru matematika terkait pelaksanaan kurikulum 2013 pada pembelajaran matematika di kelas, tinjauan teori tentang model PBL, AfL, dan penggunaan media smartphone pada pembelajaran, dengan tujuan untuk mengembangkan model PBL dengan menggunakan penilaian AfL serta memanfaatkan media smartphone. 
2. Development or prototyping phase: Pada fase ini dikembangkan prototipe berupa komponen model pembelajaran PBL-AfL-S beserta perangkat pembelajarannya, kemudian diadakan penilaian oleh validator ahli untuk mendapatkan model PBL-AfL-S beserta perangkat pembelajarannya yang valid.

3. Assessment phase: Pada fase ini dilakukan uji coba prototipe untuk menilai apakah prototipe memenuhi kriteria kepraktisan dan keefektifan. Desain penelitian pengembangan model Plomp yang digunakan pada penelitian ini ditunjukkan pada gambar 1 berikut.

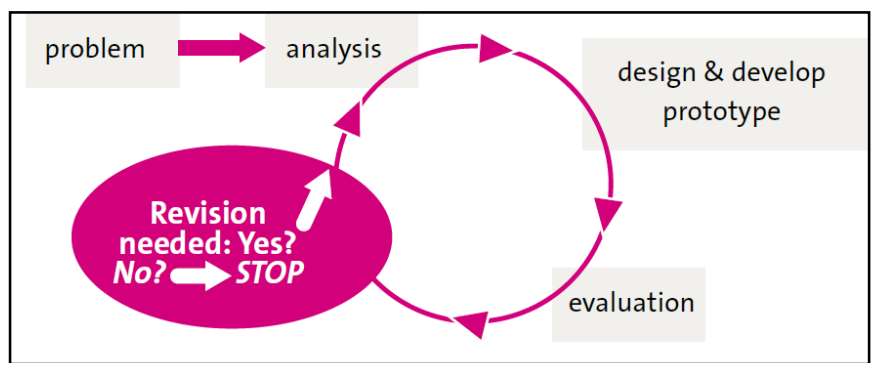

Gambar 1. Desain Penelitian Pengembangan Model Plomp (2013)

Menurut Neiveen (1999), intervensi yang memiliki kualitas tinggi harus memenuhi kriteria valid, praktis, dan efektif. Hal inilah yang dijadikan dasar untuk mengembangkan model PBL-AfL-S pada penelitian ini. Penelitian ini mengembangkan model PBL-AfL-S beserta perangkatnya. Komponen yang dirancang pada model PBL-AfL-S adalah sintaks pembelajaran, sistem sosial, prinsip reaksi, sistem pendukung, serta dampak pembelajaran dan dampak pengiring. Perangkat pembelajaran yang dikembangkan meliputi rencana pelaksanaan pembelajaran (RPP), lembar kerja siswa (LKS), Lembar Tugas Siswa (LTS), dan media smartphone. Instrumen pada penelitian ini adalah lembar validasi model pembelajaran, lembar validasi RPP, lembar validasi LKS, lembar validasi LTS, lembar validasi media smartphone, lembar validasi aktivitas guru dan siswa, lembar validasi tes prestasi belajar, lembar validasi penilaian diri, lembar validasi penilaian proyek, dan lembar validasi angket respon siswa.

Pada tahap pengembangan atau prototyping, instrumen divalidasikan kepada dua validator ahli (validator 1 ahli dalam bidang pendidikan matematika dan validator 2 ahli dalam bidang aljabar). Setelah instrumen 
dinyatakan valid oleh kedua validator ahli, maka instrumen tersebut sudah bisa digunakan untuk menilai kevalidan model PBL-AfL-S dan perangkat pembelajarannya. Terdapat tiga validator yang ahli pada bidang pendidikan matematika untuk melaksanakan validasi terhadap model PBLAfL-S dan perangkat pembelajarannya. Apabila model PBL-AfL-S dan perangkat pembelajarannya sudah dinyatakan valid, maka dapat dilanjutkan ke tahap evaluasi. Pada tahap ini dilaksanakan uji coba model PBL-AfL-S dan perangkat pembelajaran untuk menilai kepraktisan dan keefektifannya. Kepraktisan model PBL-AfL-S dan perangkat pembelajarannya dapat dinilai dari hasil observasi aktivitas guru dan aktvitas siswa selama proses pembelajaran berlangsung. Keefektifan model PBL-AfL-S dan perangkat pembelajarannya dinilai dari hasil tes prestasi belajar (TPB), angket penilaian diri, penilaian proyek, dan respon siswa. Untuk hasil TPB harus memenuhi kriteria nilai rata-rata 70 dan persentasi siswa yang mencapai KKM sebesar 75\%. Kriteria ini diambil karena nilai KKM matematika di SMA Negeri 3 Klaten adalah 70 dan pembelajaran dikatakan memenuhi ketuntasan klasikal jika minimal $75 \%$ siswa dalam satu kelas tuntas KKM.

Uji coba model PBL-AfL-S dan perangkat pembelajarannya dilaksanakan di SMA Negeri 3 Klaten. Uji coba ini terdiri dari dua tahap. Uji coba pertama dilaksanakan di kelas XI-IPA-6 selama tiga pertemuan dan uji coba kedua dilaksanakan di kelas XI-IPA-7 selama lima pertemuan. Kelas XI-IPA-6 terdiri dari 35 siswa dan XI-IPA-7 terdiri dari 30 siswa.

\section{Temuan dan Pembahasan}

Berikut disajikan hasil penelitian terkait pengembangan model PBLAfL-S dan perangkat pembelajarannya.

1. Fase Penelitian Pendahuluan (Preliminary research phase)

Pengembangan model PBL-AfL-S ini didasarkan atas teori belajar konstruktivis. Teori konstruktivis menyatakan bahwa informasi baru yang individu dapatkan didasarkan pada pengetahuan yang telah dimilikinya, dan membangun pemahaman baru serta lebih luas tentang dunia di sekitarnya (Piaget \& Inhelder, 1973). Pengembangan model PBL-AfL-S ini juga didasarkan atas teori konstrusktivis sosial dari Vygotsky (1978) yang menyatakan bahwa perlu adanya interaksi sosial dalam proses membangun pengetahuan yang memainkan peran sentral dalam 
membuat makna dalam belajar. Berdasarkan hasil observasi dan wawancara dengan guru matematika SMA Negeri 3 Klaten, pelaksanaan penilaian formatif pada implementasi kurikulum 2013 kurang optimal sehingga diperlukan penilaian AfL yang menekankan pada penilaian formatif yang diintegrasikan dengan media komunikasi smartphone untuk mendukung proses konstuksi pengetahuan pada pelaksanaan model PBL, dimana pembelajaran tidak hanya berlangsung di kelas, tetapi juga berlangsung di luar kelas.

2. Fase Pengembangan (Development or Prototyping phase) Hasil validasi instrumen penelitian oleh dua validator ahli ditunjukkan oleh Tabel 1 berikut.

Tabel 1. Hasil Validasi Instrumen Penelitian

\begin{tabular}{|l|l|l|l|l|l|}
\hline \multirow{2}{*}{ No } & Jenis Instrumen & $\begin{array}{l}\text { Validitas } \\
\text { Rata- } \\
\text { Rata }\end{array}$ & Ket. & $\begin{array}{l}\text { Nilai } \\
\text { Precentage of } \\
\text { Agreement }\end{array}$ & Ket. \\
\hline 1 & $\begin{array}{l}\text { Lembar Validasi } \\
\text { Model PBL-AfL-S }\end{array}$ & 4,585 & $\begin{array}{l}\text { sangat } \\
\text { valid }\end{array}$ & $100 \%$ & Reliabel \\
\hline 2 & $\begin{array}{l}\text { Lembar Validasi } \\
\text { RPP }\end{array}$ & 4,405 & Valid & $95,745 \%$ & Reliabel \\
\hline 3 & $\begin{array}{l}\text { Lembar Validasi } \\
\text { LKS }\end{array}$ & 4,375 & Valid & $87,500 \%$ & Reliabel \\
\hline 4 & $\begin{array}{l}\text { Lembar Validasi } \\
\text { LTS }\end{array}$ & 4,438 & Valid & $87,500 \%$ & reliabel \\
\hline 5 & $\begin{array}{l}\text { Lembar Validasi } \\
\text { Media } \\
\text { Smartphone }\end{array}$ & 4,444 & Valid & $88,889 \%$ & reliabel \\
\hline 6 & $\begin{array}{l}\text { Lembar Validasi } \\
\text { Aktivitas Guru }\end{array}$ & 4,352 & Valid & $88,889 \%$ & reliabel \\
\hline 7 & $\begin{array}{l}\text { Lembar Validasi } \\
\text { Aktivitas Siswa }\end{array}$ & 4,467 & Valid & $90 \%$ & reliabel \\
\hline 8 & $\begin{array}{l}\text { Lembar Respon } \\
\text { Siswa }\end{array}$ & 4,556 & Valid & $88,889 \%$ & reliabel \\
\hline 9 & $\begin{array}{l}\text { Lembar } \\
\text { Penilaian Diri }\end{array}$ & 4,425 & Valid & $90 \%$ & reliabel \\
\hline 10 & $\begin{array}{l}\text { Lembar } \\
\text { Penilaian Proyek }\end{array}$ & 4,583 & Valid & $100 \%$ & reliabel \\
\hline 11 & $\begin{array}{l}\text { Tes Prestasi } \\
\text { Belajar (TPB) }\end{array}$ & 4,704 & Valid & $100 \%$ & reliabel \\
\hline
\end{tabular}


Berdasarkan hasil validasi dan reliabilitas, instrumen penelitian dapat dikatakan telah valid dan reliabel sehingga instrumen penelitian dapat digunakan untuk mengambil data penelitian.

Proses validasi model PBL-AfL-S dilaksanakan validator dengan meninjau buku model PBL-AfL-S. Validasi model PBL-AfL-S pada penelitian ini dilakukan oleh tiga validator ahli yang merupakan dosen program studi pendidikan matematika Universitas Widya Dharma Klaten. Validitas untuk PBL-AfL-S terdiri dari validitas konstruk dan validitas isi. Validitas konstruk menunjukkan bahwa model tersebut dikembangkan berdasarkan rasional teoritik yang kuat. Berdasarkan hasil validitas konstruk diperoleh informasi bahwa nilai rata-rata validasi untuk aspek 1 dan aspek 2 adalah 4,853 dengan kategori sangat valid. Hal ini berarti bahwa validitas konstruk prototipe I memenuhi validitas konstruk. Berdasarkan hasil validitas isi diperoleh informasi bahwa nilai rata-rata validasi untuk aspek 3 sampai dengan 8 adalah 4,470 dengan kateori valid. Hal ini berarti bahwa validitas konstruk prototipe I memenuhi validitas isi.

Hasil validasi perangkat pembelajaran PBL-AfL-S dari tiga validator ahli ditunjukkan pada Tabel 2 berikut.

Tabel 2. Hasil Validasi Perangkat Pembelajaran PBL-AfL-S

\begin{tabular}{|l|l|c|c|}
\hline No & \multicolumn{1}{|c|}{ Jenis Perangkat } & Skor Rata-Rata & Katerangan \\
\hline 1 & RPP & 4,413 & valid \\
\hline 2 & LKS & 4,458 & valid \\
\hline 3 & LTS & 4,438 & valid \\
\hline 4 & Media Smartphone & 4,407 & valid \\
\hline
\end{tabular}

Berdasarkan hasil validasi model PBL-AfL-S dan perangkat pembelajarannya, maka prototipe I dapat dikatakan telah memenuhi kriteria valid dengan sedikit masukan dari validator. Setelah memenuhi kriteria valid, prototipe I ini menjadi prototipe II yang siap untuk diujicobakan di kelas XI-IPA-6 untuk menilai kepraktisan dan keefektifannya.

Hasil uji coba PBL-AfL-S dan perangkat pembelajarannya selama tiga kali pertemuan ditunjukkan oleh Tabel 3 dan Tabel 4.

Tabel 3. Hasil Uji Coba Tahap I tentang Kepraktisan Model PBL-AfL-S

\begin{tabular}{|l|l|c|l|}
\hline No & \multicolumn{1}{|c|}{ Jenis Observasi } & Nilai Rata-Rata & \multicolumn{1}{|c|}{ Kategori } \\
\hline 1 & Aktivitas Guru & 3,967 & Baik \\
\hline 2 & Aktivitas Siswa & 3,367 & Cukup Baik \\
\hline
\end{tabular}


Karena aktivitas siswa termasuk kategori cukup baik (belum termasuk kategori baik), maka dapat dikatakan bahwa model PBL-AfL-S belum memenuhi kriteria kepraktisan.

Tabel 4. Hasil Uji Coba Tahap I tentang Keefektifan Model PBL-AfL-S

\begin{tabular}{|l|l|c|l|}
\hline No & Jenis Penilaian & Nilai Rata-Rata & Kategori \\
\hline 1 & Penilaian Diri & 4,079 & Baik \\
\hline 2 & Penilaian Proyek & 4,011 & Baik \\
\hline 3 & Tes Prestasi Belajar & 77,229 & Tinggi \\
\hline 4 & Respon Siswa & 3,569 & Menyenagkan \\
\hline
\end{tabular}

Siswa yang tuntas KKM adalah 24 dari 35 siswa, dengan persentase ketuntasan $68,571 \%$ (belum mencapai $75 \%$ ). Hal inilah yang menyebabkan model PBL-AfL-S belum memenuhi kriteria keefektifan.

\section{Evaluasi Pelaksanaan Pembelajaran Model PBL-AfL-S}

Karena model PBL-AfL-S belum memenuhi kriteria kepraktisan dan keefektifan, maka perlu diadakan evaluasi demi perbaikan tentang kekurangan yang muncul. Evaluasi dilaksanakan dengan mengacu pada hasil uji coba tahap I serta diskusi antara peneliti dan guru yang bersangkutan untuk mengatasi permasalahan yang muncul.

Hasil peninjauan ulang dan refleksi terhadap pelaksanaan pembelajaran pada siklus ini berupa revisi terhadap frekuensi pertemuan dan perangkat pembelajaran. Beberapa pokok revisi yang dilakukan ditampilkan pada Tabel 5 berikut.

Tabel 5. Pokok Revisi Prototipe II

\begin{tabular}{|c|c|c|c|c|}
\hline No & Komponen & Sebelum Direvisi & $\begin{array}{l}\text { Sesudah } \\
\text { Direvisi }\end{array}$ & Rasional \\
\hline 1 & $\begin{array}{l}\text { Frekuensi } \\
\text { Pertemuan }\end{array}$ & $\begin{array}{l}\text { Pembelajaran } \\
\text { dilaksanakan hanya } \\
3 \text { kali pertemuan. } \\
\text { Sementara pada } \\
\text { pertemuan ke-2 } \\
\text { terdiri dari } 4 \text { tujuan } \\
\text { pembelajaran dan } \\
\text { pertemuan ke-3 } \\
\text { terdiri dari } 3 \text { tujuan } \\
\text { pembejaran ranah } \\
\text { kognitif. Hal inilah } \\
\text { yang dinilai }\end{array}$ & $\begin{array}{l}\text { Pembelajaran } \\
\text { dilaksanakan } \\
\text { selama } 5 \text { kali } \\
\text { pertemuan, } \\
\text { dengan masing- } \\
\text { masing } \\
\text { pertemuan } \\
\text { mempunyai } \\
\text { maksimal } 2 \\
\text { tujuan } \\
\text { pembelajaran } \\
\text { ranah kognitif. }\end{array}$ & $\begin{array}{l}\text { Pembelajaran } \\
\text { akan lebih } \\
\text { efesien, } \\
\text { sehingga guru } \\
\text { dan siswa akan } \\
\text { lebih maksimal } \\
\text { melaksanakan } \\
\text { pembelajaran } \\
\text { yang sudah } \\
\text { dirancang } \\
\text { sesuai dengan } \\
\text { RPP. }\end{array}$ \\
\hline
\end{tabular}




\begin{tabular}{|c|c|c|c|c|}
\hline No & Komponen & Sebelum Direvisi & $\begin{array}{l}\text { Sesudah } \\
\text { Direvisi }\end{array}$ & Rasional \\
\hline & & $\begin{array}{l}\text { menjadikan } \\
\text { pembelajaran } \\
\text { kurang efesien. }\end{array}$ & & \\
\hline 2 & LKS & $\begin{array}{l}\text { Terdapat } 3 \text { jenis LKS } \\
\text { untuk masing- } \\
\text { masing pertemuan, } \\
\text { di mama masing- } \\
\text { masing LKS terdiri } \\
\text { dari } 2 \text { atau lebih } \\
\text { tujuan } \\
\text { pembelajaran } \\
\text { ranah kognitif. }\end{array}$ & $\begin{array}{l}\text { Terdapat } 5 \text { jenis } \\
\text { LTS untuk } \\
\text { masing-masing } \\
\text { pertemuan ( } 5 \\
\text { pertemuan), } \\
\text { dengan masing- } \\
\text { masing LKS } \\
\text { terdiri maksimal } \\
2 \text { tujuan } \\
\text { pembelajaran } \\
\text { ranah kognitf. }\end{array}$ & $\begin{array}{l}\text { Tujuan } \\
\text { pembelajaran } \\
\text { pada masing- } \\
\text { masing LKS } \\
\text { akan lebih } \\
\text { mudah untuk } \\
\text { dicapai. }\end{array}$ \\
\hline 3 & LTS & $\begin{array}{l}\text { Terdapat } 3 \text { jenis LTS } \\
\text { untuk masing- } \\
\text { masing pertemuan } \\
\text { ( } 3 \text { pertemuan). }\end{array}$ & $\begin{array}{l}\text { Terdapat } 5 \text { jenis } \\
\text { LTS untuk } \\
\text { masing-masing } \\
\text { pertemuan ( } 5 \\
\text { pertemuan). }\end{array}$ & $\begin{array}{l}\text { Semua tujuan } \\
\text { pembelajaran } \\
\text { ranah kognitif } \\
\text { akan dapat } \\
\text { dijangkau } \\
\text { dalam soal } \\
\text { dalam LTS. }\end{array}$ \\
\hline
\end{tabular}

Setelah model PBL-AfL-S direvisi, kemudian diujicobakan lagi di kelas IX-IPA 7 untuk memenuhi kriteria kepraktisan dan keefektifan. Model PBLAfL-S yang diujicobakan pada tahap II ini dalam bentuk prototipe $\mathrm{II}_{2}$. Pelaksanaan pembelaajran pada tahap II dilaksanakan selama 5 kali pertemuan. Hasil uji coba tahap II ditunjukkan oleh Tabel 6 dan Tabel 7.

Tabel 6. Hasil Uji Coba Tahap II tentang Kepraktisan Model PBL-AfL-S

\begin{tabular}{|l|l|c|c|}
\hline No & Jenis Observasi & Nilai Rata-Rata & Kategori \\
\hline 1 & Aktivitas Guru & 4,160 & Baik \\
\hline 2 & Aktivitas Siswa & 4,147 & Baik \\
\hline
\end{tabular}

Karena aktivitas guru termasuk kategori baik dan aktivitas siswa termasuk kategori baik, maka dapat disimpulkan bahwa model PBL-AfL-S telah memenuhi kriteria kepraktisan. 
Tabel 7. Hasil Uji Coba Tahap II tentang Keefektifan Model PBL-AfL-S

\begin{tabular}{|l|l|l|l|}
\hline No & Jenis Penilaian & Nilai Rata-Rata & Kategori \\
\hline 1 & Penilaian Diri & 4,353 & Baik \\
\hline 2 & Penilaian Proyek & 4,483 & Baik \\
\hline 3 & Tes Prestasi Belajar & 80,067 & Tinggi \\
\hline 4 & Respon Siswa & 4,113 & Menyenangkan \\
\hline
\end{tabular}

Berdasarkan informasi pada Tabel 7, dapat dikatakan bahwa model PBL-AfL-S telah memenuhi kriteria keefektifan. Berdasarkan hasil penelitian yang telah dipaparkan, diperoleh informasi bahwa model PBLAfL-S dan perangkat pembelajarannya yang dikembangkan telah memenuhi kriteria valid, praktis, dan efektif.

\section{Hasil Pengembangan Model PBL-AfL-S}

Berikut hasil pengembangan model PBL-AfL-S dan perangkat pembelajarannya dengan mengacu pada komponen-komponen model pembelajaran.

a. Sintaks

Langkah-langkah model pembelajaran PBL-AfL-S pada penelitian ini mengombinasikan langkah-langkah pada model pembelajaran PBL dengan model penilaian AfL berbantuan smartphone yang beracuan pada Standar Proses Kurikulum 2013 yang telah direvisi pada tahun 2016. Model PBLAfL-S ini terdiri dari 5 fase, yaitu: Fase 1, memberikan orientasi tentang permasalahan kepada siswa).Fase 2, mengorganisasikan siswa untuk meneliti); Fase 3 (membantu investigasi mandiri dan kelompok. Fase 4, mengembangkan dan mempresentasikan artefak dan exhibit. Dan fase 5, menganalisis dan mengevaluasi proses mengatasi masalah. Pada fase 1 guru memberikan masalah tentang garis singgung dan limit fungsi. Pada fase 2 guru memberikan kesempatan kepada siswa untuk mengumpulkan data dari berbagai sumber untuk memecahkan masalah yang diberikan. Pada fase 3 guru memberikan kesempatan kepada siswa untuk mengolah data yang sudah diperoleh untuk memecahkan masalah. Pada fase 4 guru memfasilitasi kegiatan presentasi siswa dan diskusi antarkelompok. Pada fase 5 dilaksanakan penilaian AfL. Berikut pelaksanaan AfL dalam pembelajaran PBL-AfL-S:

1) Guru membantu siswa untuk melakukan refleksi terhadap investigasinya dan proses-proses yang mereka gunakan melalui 
model penilaian AfL. Model penilaian AfL pada langkah tersebut dilakukan dengan memberikan soal kepada siswa untuk mendapatkan umpan balik dari hasil belajarnya.

2) Pemberian soal bertahap (terdiri dari tiga tahap). Soal tahap I termasuk kategori mudah, soal tahap II termasuk kategori mudah atau sedang, serta soal tahap III termasuk kategori sedang atau sukar.

3) Soal tahap I langsung dikerjakan di kelas dan langsung diperiksa oleh guru (atau oleh tim penilai) dan dikembalikan kepada siswa pada saat itu juga. Umpan balik diberikan bagi siswa yang melakukan kesalahan. Jawaban soal siswa diberi skor, tetapi skor tidak diberitahukan kepada siswa. Fungsi pemberian skor adalah untuk merekam kemajuan siswa, bukan sebagai bagian dari pemberian nilai kepada siswa.

4) Prosedur pemberian soal tahap II hampir sama dengan soal tahap I. Akan tetapi, soal tahap II dikerjakan di kelas dan diserahkan kepada guru sebelum pertemuan berikutnya. Penyerahan hasil pekerjaan ini menggunakan smartphone dengan memanfaatkan aplikasi WhatsApp (WA). Cara penyerahan hasil pekerjaan lewat WA adalah dengan cara mengambil gambar (memotret) hasil pekerjaan kemudian mengirimkannya ke akun WA guru pengampunya. Selanjutnya guru memberikan umpan balik hasil pekerjaan siswa dengan mengirimkan dalam bentuk berkas foto ke akun siswa yang bersangkutan. Bagi siswa yang tidak mempunyai smartphone penyerahan hasil pekerjaan dapat berupa lembar hasil pekerjaan siswa dan dikumpulkan sebelum pertemuan berikutnya.

5) Pemberian soal tahap III berfungsi sebagai pekerjaan rumah seperti yang bisanya diberikan oleh guru kepada siswanya. Jawaban soal-soal tahap III ini didiskusikan di kelas, tetapi pada model ini tidak ada kewajiban bagi guru untuk memeriksa dan memberi balikan secara tertulis kepada masing-masing siswa.

b. Prinsip-Prinsip Reaksi

Dalam pembelajaran matematika dengan model PBL-AfL-S kemungkinan besar dijumpai siswa yang mengalami kesulitan dalam mengkonstruksi pengetahuan atau dalam memecahkan masalah; siswa tersebut diberi kesempatan bertanya kepada guru tentang kesulitan yang 
dihadapinya. Guru memberi bantuan secukupnya kepada siswa yang mengalami kesulitan tersebut.

\section{c. Sistem Sosial}

Dalam model pembelajaran PBL-AfL-S ini kegiatan berpusat pada siswa, peran guru sebagai fasilitator, motivator, organisator, moderator, dan evaluator. Sebagai fasilitator guru menyediakan sumber-sumber belajar dan mendorong semangat siswa belajar, dan memberi bantuan kepada siswa agar siswa dapat mengkonstruksi pengetahuan matematis secara optimal. Sebagai motivator, guru memberikan motivasi di awal pembelajaran dengan memberikan pertanyaan berkaitan dengan materi prasyarat yang berfungsi sebagai pengait antara pengetahuan yang dimiliki siswa dengan pengetahuan yang akan dibangun oleh siswa. Sebagai organisator, guru mengatur dan mendorong siswa agar kegiatan pembelajaran dapat terlaksana dengan baik dan lancar, serta memastikan para siswanya melakukan kegiatan dengan sebaik-baiknya. Sebagai moderator, guru memimpin dan mengatur diskusi kelompok dan diskusi kelas sehingga pelaksanaan tanya jawab dapat berlangsung dengan lancar dan tertib. Sebagai evaluator, guru memberikan penilaian dan umpan baliknya untuk memotivasi siswa supaya lebih meningkatnya usahanya dalam belajar.

\section{d. Sistem Pendukung}

Sistem pendukung dalam pembelajaran pada penelitian ini adalah segala rencana dan alat yang diperlukan untuk melaksanakan model pembelajaran PBL-AfL-S. Pendukung model PBL-AfL-S terdiri dari sejumlah bahan dan media pembelajaran. Pendukung utama dalam pembelajaran ini adalah RPP, LKS, dan LTS. Sedangkan pendukung pendampingnya adalah smartphone dengan memanfaatkan aplikasi WhatsApp (WA).

\section{e. Dampak Pembelajaran dan Dampak Pengiring}

Dampak pembelajaran model PBL-AfL-S pada penelitian ini adalah hasil belajar siswa pada ranah kognitif, afektif, dan psikomotorik. Sementara dampak pengiring PBL-AfL-S pada penelitian ini adalah menjadi bahan pertimbangan dalam mengembangkan kurikulum ke arah yang lebih baik. Keberhasilan pengembangan model PBL-AfL-S dan perangkat 
pembelajarannya ini sejalan dengan beberapa hasil penelitian yang relevan dengan penelitian ini. Berikut beberapa penelitian yang relevan dengan penelitian ini.

Hasil penelitian Angkotasan (2014) menunjukkan bahwa model pembelajaran Problem Based Learning efektif ditinjau dari kemampuan pemecahan masalah matematis pada siswa SMA Negeri 5 Kota Ternate. Hasil penelitian Paloloang (2014) menunjukkan bahwa model PBL dapat meningkatkan hasil belajar siswa pada materi panjang garis singgung persekutuan dua lingkaran. Hasil penelitian Mustofa, Susilo, dan Muhdar (2016) menunjukkan bahwa penerapan model Problem Based Learning melalui pendekatan kontekstual berbasis Lesson Study dapat meningkatkan kemampuan memecahkan masalah dan hasil belajar kognitif siswa SMA. Hasil penelitian Sari (2016) menunjukkan bahwa penerapan model Problem Based Learning dapat meningkatkan kemampuan pemecahan masalah matematika siswa kelas XI-IPA SMA pada materi program linear.

Hasil penelitian Suparmo, Budiyono, dan Sutanto (2013) menunjukkan bahwa siswa yang dikenai pembelajaran AfL dengan pendekatan teman sejawat mempunyai prestasi belajar yang lebih baik daripada siswa yang dikenai pembelajaran langsung. Hasil kajian Tan (2013) menunjukkan bahwa desain penilaian, praktik umpan balik siswa, dan kejelasan standar untuk dipahami sebagai seperangkat praktik penilaian yang koheren dalam hubungan satu sama lain. Hasil penelitian Isabwe, Reichert, Carlsen, dan Lian (2014) menyatakan bahwa siswa memperoleh keuntungan dengan diterapkannnya model AfL pada pembelajaran di kelas. Siswa dapat menilai kinerjanya sendiri dan temannya. Siswa saling memberikan dan memberikan umpan balik terkait hasil perkerjaannya.Siswa dapat menggunakan alat yang didukung teknologi sangat tinggi untuk menghargai pembelajaran matematis mereka sendiri. Hasil penelitian Sudiyanto (2015) menyatakan bahwa model Assessment forLearning dapat meningkatkan kompetensi akuntasi siswa SMK. Berdasarkan beberapa hasil penelitian tersebut, dapat dikatakan bahwa model Assessment for Learning (AfL) dapat meningkatkan motivasi, kepercayaan diri, dan kemampuan akademik peserta didik. 
Berikut ini terdapat penelitian terkait pemanfaatan smartphone untuk mendukung pembelajaran matematika. Hasil penelitian Bouhnik dan Deshen (2014) menunjukkan bahwa responden menyebutkan keunggulan teknis dari WhatsApp, seperti operasi sederhana, biaya rendah, ketersediaan, dan kedekatan. Mereka juga mengacu pada keuntungan pendidikan, seperti penciptaan lingkungan yang menyenangkan dan pengenalan mendalam dengan sesama siswa, yang memiliki pengaruh positif terhadap cara percakapan. Peserta juga menunjukkan keunggulan akademis seperti aksesibilitas materi pembelajaran, ketersediaan guru, dan kelanjutan pembelajaran di luar jam kelas. Hasil penelitian Juwita, Budimansyah dan Nurbayani (2015) menunjukkan bahwa media sosial memberikan dampak positif terhadap gaya hidup remaja di SMAN 5 Bandung. Dampak positif tersebut adalah adanya media sosial dapat membuat komunikasi semakin mudah dan arus informasi semakin cepat. Hasil penelitian Winardi dan Wardono (2017) menunjukkan bahwa siswa yang memperoleh pembelajaran Missouri Mathematics Project dengan pendekatan open-ended berbantuan WhatsApp mempunyai kemandirian belajar matematika yang baik. Tugas matematika yang diberikan oleh guru dapat diselesaikan siswa dengan baik melalui grup diskusi pada WhatsApp. Hasil penelitian Kartikawati dan Pratama (2017) menunjukkan bahwa siswa yang diberi pembelajaran Group Investigation terintegrasi media sosial WhatsApp mempunyai kemampuan berpikir kritis yang lebih baik daripada siswa yang diberi pembelajaran langsung.

Kendala yang dihadapi peneliti ketika pelaksanaan penelitian adalah sebagai berikut. Kendala pertama adalah terdapat satu siswa yang belum memiliki smartphone, sehingga pelaksanaan AfL di luar kelas sulit dilaksanakan untuk siswa tersebut. Solusinya adalah hasil pekerjaan rumah siswa tersebut harus dikumpulkan sebelum pertemuan berikutnya dilaksanakan supaya guru bisa mengoreksi terlebih dahulu dan memberikan umpan balik. Kendala yang kedua adalah masih terdapat beberapa siswa yang belum menguasai materi gradien suatu garis dan konsep limit fungsi sebagai materi prasyarat, sehingga guru perlu menjelaskannya terlebih dahulu. 


\section{Simpulan}

Berdasarkan analisis hasil penelitian, model Problem Based Learning (PBL) dengan menggunakan model penilaian Assessment for Learning (AfL) berbatuan smartphone dan perangkat pembelajarannya memenuhi kriteria valid, praktis dan efektif. Saran yang diberikan pada penelitian ini, yaitu: 1) model PBL-AfL-S dapat dijadikan alternatif pembelajaran matematika di sekolah untuk mendukung implementasi kurikulum 2013; 2) penelitian ini hanya terbatas pada kelas XI-IPA saja, sehingga diharapkan dapat mengimplementasikannya di kelas yang lain (seperti kelas X dan XII); dan 3) guru juga dapat menguji tingkat keterlaksanaan pembelajaran matematika dengan model PBL-AfL-S ini, misalnya melalui penelitian tindakan kelas.

\section{Ucapan Terima Kasih}

Terima kasih peneliti sampaikan kepada Direktorat Riset dan Pengabdian kepada Masyarakat, Direktorat Jenderal Penguatan Riset dan Pengembangan Kementerian Riset, Teknologi, dan Pendidikan Tinggi yang telah mendanai pelaksanaan penelitianini. Terima kasih juga peneliti sampaikan kepada Ibu Detalia Noriza Munahefi, M.Pd., guru matematika kelas XI IPA SMA Negeri 3 Klaten yang telah membantu dalam wawancara, perencanaan pembelajaran, dan pelaksanaan pembelajaran pada penelitian ini.

\section{Daftar Pustaka}

Angkotasan, N. (2014). Keefektifan model problem-based learning ditinjau dari kemampuan pemecahan masalah matematis. Delta-Pi-Jurnal Matematika dan Pendidikan Matematika, 3(3), 11-19.

Azmi, B., Irzani, I., \& Khusnial, N. (2014). Efektivitas strategi problem based learning (pbl) terhadap kemampuan berfikir kreatif peserta didik. Beta Jurnal Tadris Matematika, 7(2), 108-119.

Badan Penelitian dan Pengembangan Kementerian Pendidikan dan Kebudayaan. (2014). Persentase penguasaan materi soalmatematika ujian nasional SMA/MA tahun pelajaran 2014/2015. Diakses di http://118.98.234.50/lhun/daya serap.aspx

Barrows, H.S. (1988). The tutorial process. Springfield Ill: Southern Illinois University School of Medicine.

Bashith, A. \& Amin, S. (2017). The effect of problem based learning on EFL students' critical thinking skill and learning outcome. Al-Ta'lim Journal, 24(2), 
93-102.

Diakses

di

http://journal.tarbiyahiainib.ac.id/index.php/attalim/article/view/271/231

Bouhnik, D. \& Deshen,M.(2014). WhatsAppgoes to school: Mobile instant messaging between teachers and students. Journal of Information Education: Research, 13, 217-231. Diakses

dihttp://www.jite.informingscience.org/documents/Vol13/JITEv13ResearchP2 17-231Bouhnik0601.pdf

Flórez, M. T. \& Sammons, P. (2013).Assessment for learning: Effect and impact. London: Oxford University Department of Education.

Isabwe, G. M. N.,Reichert, F., Carlsen, M., \& Lian, T. A. (2014).Using assessment for learning mathematics with mobile tablet based solutions. International Journal of Emerging Technologies in Learning, 9(2), 29-36. Diakses dihttp://online-journals.org/index.php/i-jet/article/view/3219.

Juwita, E. P., Budimansyah, D., \& Nurbayani, S. (2015). Peran media sosial terhadap gaya hidup siswa SMA Negeri 5 Bandung. Jurnal Sosietas, 5(1).

Diakses

http://ejournal.upi.edu/index.php/sosietas/article/download/1513/1039

Kartikawati, S. \& Pratama, H. (2017).Pengaruh penggunaan WhatsApp Messengersebagai mobile learning terintegrasi metode group investigationterhadap kemampuan berpikir kritis. JUPITER (Jurnal Pendidikan Teknik Elektro), 2(2), 33-38. Diakses di http://ejournal.unipma.ac.id/index.php/JUPITER/article/view/1797/1391

Mustofa, Z., Susilo, H., \& Muhdar, M. H. I, A. (2016). Penerapan model pembelajaran problem based learning melalui pendekatan kontekstual berbasis lesson study untuk meningkatkan kemampuan memecahkan masalah dan hasil belajar kognitif siswa SMA. Jurnal Pendidikan: Teori, Penelitian, dan Pengembangan, 1(5), 885-889. Diakses di http://journal.um.ac.id/index.php/jptpp/article/view/6298/2688

Negara, H. (2015). Eksperimentasi model pembelajaran kooperatif tipe think pair share (TPS) dengan assessment for learning (Afl) terhadap prestasi belajar dan kemampuan komunikasi matematis pada materi segiempat ditinjau dari gaya kognitif siswa. Beta Jurnal Tadris Matematika, 8(2), 163-182.

Naidoo, J. \& Kopung, K. J. (2016). Exploring the use of whatsApp in mathematics learning: A case study. Journal of Communication, 7(2), 266-273. Diakses di http://www.tandfonline.com/doi/abs/10.1080/0976691X.2016.11884907

Nieveen, N. (1999). Prototyping to reach product quality. In van den Akker J., Branch R.M., Gustafson K., Nieveen N., Plomp T. (Eds). Design Approaches and Tools in Education and Training. Springer: Dordrecht. pp 125-135.

Paloloang, M. F. B. (2014). Penerapan model problem based learning (PbL) untuk meningkatkan hasil belajar siswa pada materi panjang garis singgung persekutuan dua lingkarandi kelas VIII SMP Negeri 19 Palu. Jurnal Elektronik Pendidian Matematika Tadulako, 2(1), 67-77. Diakses di jurnal.untad.ac.id/jurnal/index.php/JEPMT/article/download/3232/2287

Piaget, J., \& Inhelder, B. (1973). Memory and intelligence. London: Routledge and Kegan Paul. 
Plomp, T. (2013). Educational desain research: An introduction. In T. Plomp \& N. Nieveen (Eds.). Educational Design Research. Enschede: Netherland Institute for Curriculum Development (SLO), pp. 10-51.

Risnawati, R. (2013). Pengaruh model problem based learning dengan poster session terhadap pemahaman konsep dan komunikasi matematika mahasiswa. Beta Jurnal Tadris Matematika, 6(2), 143-150.

Sani, R. A. (2014). Pembelajaran saintifik untuk implementasi kurikulum 2013. Jakarta: Bumi Aksara.

Sari, T. W. (2016).Penerapan model pembelajaran problem based learning (PBL) untuk meningkatkan kemampuan pemecahan masalah matematika siswa di kelas XI-IPA SMA Islam Al-Ulum Terpadu Medan T.A 2016/2017(Master thesis). Diakses di http://digilib.unimed.ac.id/id/eprint/20876

Sudiyanto, Kartowagiran, B., \& Mulyadi. (2015). Pengembangan model assessment as learning pembelajaran akuntansi di SMK.Jurnal Penelitian dan Evaluasi Pendidikan, 19(2), 189-201. Diakses di https://journal.uny.ac.id/index.php/jpep/article/view/5579

Suparmo, D., Budiyono, \& Sutanto. (2013). Pengembangan model assessment for learning ( $\mathrm{AfL}$ ) melalui penilaian teman sejawat pada pembelajaran matematika pada pokok bahasan trigonometri ditinjau dari gaya belajar siswa SMA Negeri Karangpandan tahun pelajaran 2012/2013. Jurnal FKIP UNS, 1(4), 411-421. Diakses

di http://jurnal.fkip.uns.ac.id/index.php/s2math/article/view/3515/2449

Ta'amneh, M. A. A. (2017). The effect of using Whatsapp messenger in learning english language among university students. International Research in Education, 5(1), 143-151.

Tan, K. (2013). A framework for assessment for learning: Implications for feedback practices within and beyond the gap (Artikel Web). Diakses di https://www.hindawi.com/journals/isrn/2013/640609

Vygotsky, L. S. (1978). Mind in society: The development of higher psychological processes. Cambridge, MA: Harvard University Press.

Winardi \& Wardono. (2017). Analisis kemampuan literasi matematika melalui model missouri mathematics project dengan pendekatan open-ended. Unnes Journal of Mathematics Education Research, 6(1), 130-138.

Yuwono, M. (2016). Analisis kesulitan mahasiswa dalam menyelesaikan soal geometri berdasarkan taksonomi bloom dan alternatif pemecahannya. Beta Jurnal Tadris Matematika, 9(2), 111-133. doi:10.20414/betajtm.v9i2.7 